\title{
Stocking rate of extensive land-reform livestock farmers during 2018/2019 drought: Bloemfontein grassland biome case study
}

Mokhesengoane, T.E. ${ }^{1}$, Van der Westhuizen, H.C. ${ }^{2}$ and Van Niekerk, J.A. ${ }^{3}$

Corresponding author: T.E. Mokhesengoane. Email: mokhesengoane@gmail.com.

\begin{abstract}
The study aimed to determine the average stocking rate among land reform beneficiary farmers specialising in livestock production in order to establish differences between calving percentage, fodder availability, and mortality rate of sampled farms, as well as to compare forage scarcities of Land Reform farms with their neighbouring farms during the midsummer drought of 2018/2019 in the Bloemfontein area. The average stocking rate was 5.9 ha/LSU in comparison with the Departmental grazing capacity norm of $6 \mathrm{ha} / \mathrm{LSU}$ for rangeland in good condition. However, $31 \%$ of the sampled farms were found to be severely overstocked, and the mortality rate on these farms, in relation to grazing capacity of $6 \mathrm{ha} / \mathrm{LSU}$, was significantly higher $(P<0.05)$ than the mortalities on the other remaining farms. Naturally available fodder was found to be heterogeneous, with $37.9 \%$ of the respondents observing their available fodder as worse than that of their neighbours. The total mortality of 176.77 LSUs was recorded for the 29 sampled farms. These findings will assist the local extension personnel prevent future rangeland condition degradation and increase land reform farmers' productivity. The study concluded that training is paramount to farmers' development and further recommends more research undertakings.
\end{abstract}

Keywords: Stocking rate; land reform farmers; drought

\section{INTRODUCTION}

Stocking rate must be considered one of the most important determinants of ecological sustainability, sustainable livestock production, and economic returns for extensive livestock farming enterprises (Van der Westhuizen et al., 2001; Van der Westhuizen et al., 2018). Tenacious over-stocking is a major contributor to veld degradation. Nonetheless, to ensure the sustainability of extensive livestock businesses and profitability, Forbes (1988) and Van der Westhuizen (2020) indicate that farmers must be in control of equating the animal forage requirements to seasonal forage production cycles and natural periods of forage scarcities. The grazing resources management decisions are heavily dependent on the temporary climatic variations in rainfall and temperature, leading to stocking rate adjustments. Over- and understocking are both detrimental to natural veld; overstocking results in

\footnotetext{
${ }^{1} \mathrm{PhD}$ student at the University of the Free State and Agricultural Extension Practitioner: Free State Department of Agriculture and Rural Development, Bloemfontein, South Africa, Email: mokhesengoane@ gmail.com, ORCID: 00000002-4492-7540

${ }^{2}$ Professional scientist: Range and Forage Science, Free State Department of Agriculture and Rural Development, Glen, South Africa, Email: mias@fs.agric.za

${ }^{3}$ Director, Head of department, Sustainable Food Systems and Development, University of the Free State,

Bloemfontein, South Africa, Email: vNiekerkJA@ufs.ac.za
} 
severe defoliation, which cripples the natural veld recovery ability post-defoliation, whereas understocking causes mould on natural veld as a result of underutilization of grazeable material, leading to a decline in both palatability and nutritional value. Thus, it is essential to always strike a balance between available natural veld and livestock numbers.

The results of not equating large stock unit (LSU) numbers to forage availability are detrimental to the natural veld. Substantial evidence by Du Preez and Snyman (1993) and by Mokhesengoane (2020) highlights that veld recovery ability post-severe defoliation is almost impossible, to the extent that seed germination and poor plant re-growth ability can result in a shift in the ecosystem state. Overstocking leads to detrimental removal of leaf area and thus retards the ability of plants to regrow. According to Mworia et al. (1997), rangeland recovery ability is heavily dependent on the grazing intensity level. The 1984 White Paper on Agricultural Policy highlighted the tremendous deterioration of natural rangelands in South Africa (Du Toit et al., 1991).

However, according to O'Connor et al. (2010) and Sanbi (2014), farmers often manage livestock with the intent to realize production goals only and not to maintain biodiversity. Thus, Dankwerts and Tainton (1996), as well as Van der Westhuizen et al. (2018), reiterate that optimization of long-term forage production quality needs rangeland deterioration prevention. This study aims to determine stocking rate and calving percentage as well as get an indication of available fodder during the midsummer drought of 2018/2019 on land-reform farms. The results of this study will assist local extension personnel in supporting Bloemfontein's extensive livestock land-reform farmers to ensure ethical, sustainable livestock production and mitigate catastrophic impacts of drought.

\section{MATERIALS AND METHODS}

\subsection{Study area}

The research was conducted on 29 land-reform farms in the magisterial district of the city of Bloemfontein in the central Free State, South Africa. Located at an average altitude of $1395 \mathrm{~m}$ above sea level, it is a semi-arid environment with an average annual rainfall of $548 \mathrm{~mm}$. The natural vegetation for livestock grazing can be described as sweet grassveld of the grassland biome, with Themeda triandra as the most distinctive and well-distributed grass species among other perennial grasses available for extensive livestock production (Acocks, 1988; Van der Westhuizen, 2003). Trees are extremely limited in plain variations of the topography, but dense stands can occur in vlei areas and hill variations. According to the Department of Agriculture and Rural Development (2003), the grazing capacity for veld in good condition is 6 ha per LSU. Unfortunately, the Departmental grazing capacity cannot be blindly applied, as veld condition varies considerably from farm to farm.

\subsection{Methods}

Twenty-nine land reform extensive livestock farmers, representing 30.8\% of the total land-reform farmers in Bloemfontein, were randomly sampled from farmers who participated in the 2018-2019 mid-summer drought assessment. Commonage, communal and all farmers who acquired their farms through private means were purposely excluded. The analysed data for this study was extracted from 
the following parts/sections of the 2018-2019 mid-summer drought assessment form: size of the grazing area, including the size of arable lands; livestock inventory part $\mathrm{C} 1$, highlighting current livestock on the farm; livestock inventory part $\mathrm{C} 2$, highlighting livestock mortalities due to drought, and the section where farmers described their available veld fodder comparing it to that of their neighbours. LSU's were calculated using metabolic body weights (Meissner et al., 1983) for mediumframed beef cattle, mutton sheep and Boer goats, as these were the prevalent livestock types kept on the sampled farms. LSU is the equivalent of an animal with a weight of $450 \mathrm{~kg}$, which gains $500 \mathrm{~g}$ per day in weight on the pasture with an average digestible energy (DE) concentration of 55\% (Meissner et al., 1983). Three per cent (3\%) of the number of matured cows and bulls were calculated as bulls since the form does not make provision for separating matured bulls from the cows. Among the studied farms, $51.7 \%$ had rain-fed arable lands, ranging from a minimum of 1 ha to 250 ha. These arable lands could not be planted for consecutive years preceding this study and were added to natural grazing areas of specific farms.

To investigate the research topic, a multi-methodological research approach was employed, namely qualitative and quantitative, as well as farmers' observations. The stocking rate was calculated as a percentage of the LSUs that can be kept on the farm using a grazing capacity of 6 ha/LSU. Farmers were grouped into five different stocking rate groups. Analysis of variance (ANOVA) was used to compare the mean values and mean differences between stocking rate and mortalities as well as between calving percentage and fodder availability. Market information was also utilized to estimate the value of the financial losses. The rainfall data were collected from the Bloemwater weather station and summarised as study area rainfall differences for a period of ten years.

\subsection{Rainfall conditions}

The South African Weather Services (SAWS) confirmed that summer rainfall areas in South Africa received below-average rains for the 2017/2018 and 2018/2019 growing seasons. Furthermore, drought was already declared in parts of the country in 2018. The Bloemfontein local weather station report further confirmed that, for both 2017/2018 and 2018/2019, below-average rainfall coupled with extremely high summer temperatures was recorded in the area. Below-average rainfall from September 2018 until the end of January 2019 for the study area, prior data collecting, also contributed to extremely dry conditions. During this period, the area only received $41 \%$ of rain in comparison with the long-term average, qualifying the study area as drought restricted. Rainfall has obvious effects on herbaceous productivity, and, as a result, rainfall timing is thus extremely important. Veld growths increased drastically in the Bloemfontein area from November until the end of February and, according to Van Der Westhuizen (2006), the average contribution to rangeland production for these four months is roughly $62 \%$. However, the later process relied on effective rains during August, September and October, which is essential for the ending of the dormant season and contributes immensely to veld quality. Van den Berg (2019) states that, for the period between October and the end of February, the Bloemfontein area experienced below-average rainfall for four out of the past five seasons (Figure 1). The aforementioned five-month period is very important for efficient fodderflow planning. The findings of Fynn and O'Connor (2000), as well as Baudoin et al. (2017) and 
Vol. 49 No. 2, 2021: 15-24

http://dx.doi.org/10.17159/2413-3221/2021/v49n2a12784

(License: CC BY 4.0)

Swemmer et al. (2018), state that the importance of rainfall on veld compositional change cannot be attributed to a single rainfall season but also to the preceding seasons.

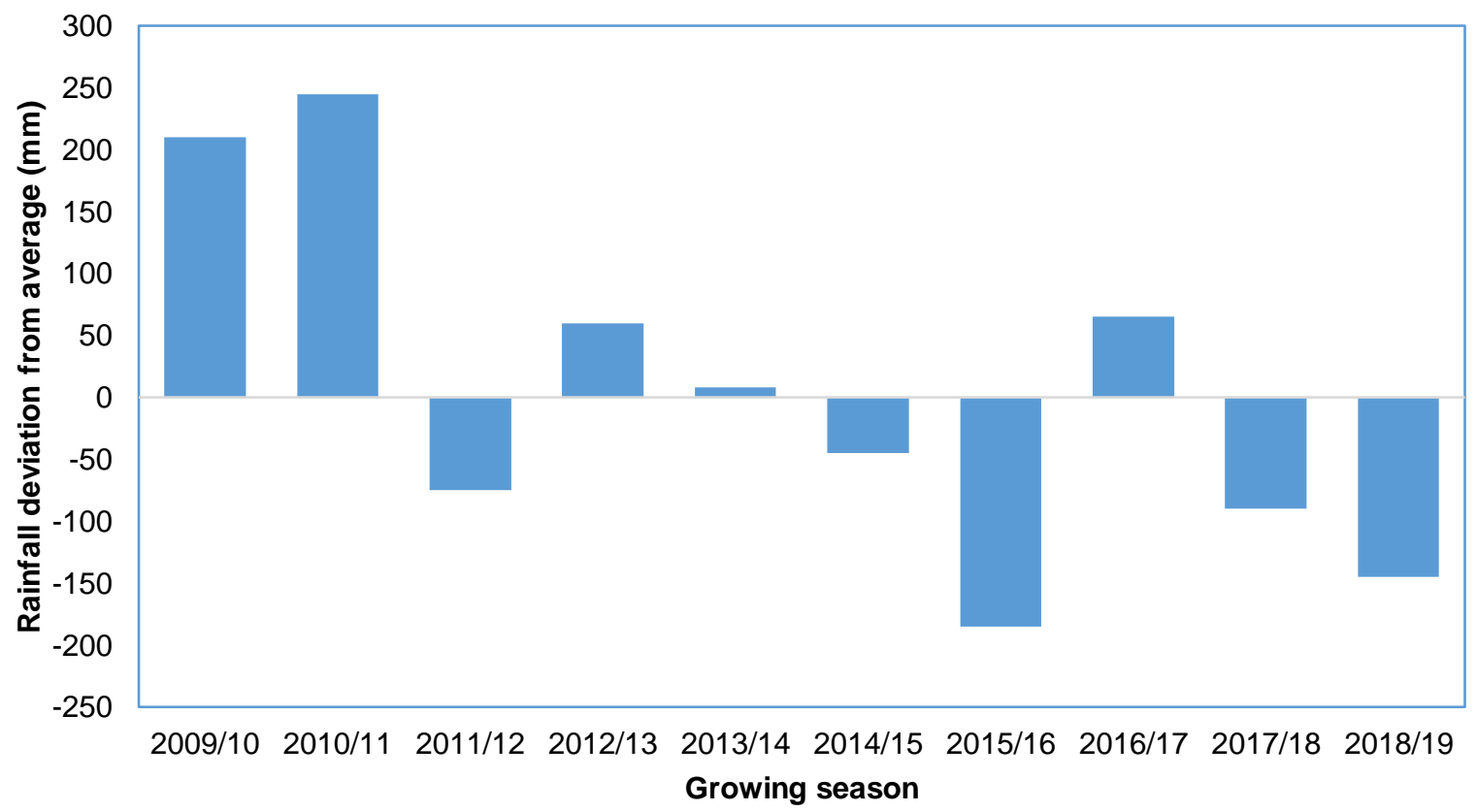

FIGURE 1: Bloemfontein rainfall differences report for a ten-year period from 1 October to 28 February (Van den Berg, 2019)

\section{RESULTS AND DISCUSSIONS}

The statistical analyses represent the decisions taken by 29 extensive land-reform livestock farmers sampled for the study during the 2018/2019 mid-summer drought in the Bloemfontein area. The data are presented in Table 1.

TABLE 1: Descriptive statistical analyses regarding grazing area, number of large stock units kept, stocking rate, mortalities, and calving rate

\begin{tabular}{|l|c|c|c|c|c|}
\hline & $\begin{array}{l}\text { Grazing area, including } \\
\text { arable lands (ha) }\end{array}$ & $\begin{array}{l}\text { Number } \\
\text { of LSUs }\end{array}$ & $\begin{array}{l}\text { Stocking rate } \\
\text { (ha/LSU) }\end{array}$ & $\begin{array}{l}\text { Mortalities } \\
\text { (LSU) }\end{array}$ & $\begin{array}{l}\text { Calving } \\
\text { rate (\%) }\end{array}$ \\
\hline Mean & 514 & 87.1 & 5.9 & 6.1 & 32 \\
\hline Median & 400 & 54.5 & 5.7 & 1.2 & 31 \\
\hline Std. deviation & 446 & 82.5 & 6.8 & 11.2 & 24 \\
\hline Range & 1566 & 311.3 & 37.5 & 55.7 & 83 \\
\hline Minimum & 4 & 4.6 & 0.2 & 0 & 0 \\
\hline Maximum & 1570 & 315.9 & 37.7 & 55.7 & 83 \\
\hline Total & 14902 & 2526.8 & & 176.8 & \\
\hline
\end{tabular}

The results show that the average number of large stock units were 87.1, allocated to the average grazing area of 514 ha. This means that the average stocking rate of sampled Bloemfontein livestock 
land-reform farmers was 5.9 ha/LSU during the 2018/2019 drought. According to these findings, the collective land-reform farmers' average stocking rate conceded with the departmental grazing capacity of the study area for veld in good condition for an average production growing season. These findings correspond with the findings of Foster (2015), where a similar parameter was measured on an extensive commercial beef-farming unit in the Zastron area, south-eastern part of the Free State province in South Africa. However, standard deviations were large, indicating a big variation in stocking rate between the different sampled Bloemfontein land-reform livestock farmers. These findings are inconsistent with good veld management practices, as highlighted by Forbes (1988:p. 01) that the "farmers must be in control of equating the animal forage requirements to seasonal forage production cycles and natural periods of forage scarcities".

According to Cros et al. (2004) as well as Zuma-Netshyukhwi and Stigter (2016), even though there is consistency on vegetation types at the farm level, the farmer has no control over prevailing weather conditions as they are dependent on the climatic conditions. However, the stocking rate is the main parameter that the farmer can control. The stocking rate was divided into different groups as indicated in Figure 2, while the mortality rate was calculated as the percentage of mortalities on every farm in relation to the number of LSUs that can be kept on the farm for veld in good condition with a grazing capacity of 6 ha/LSU.

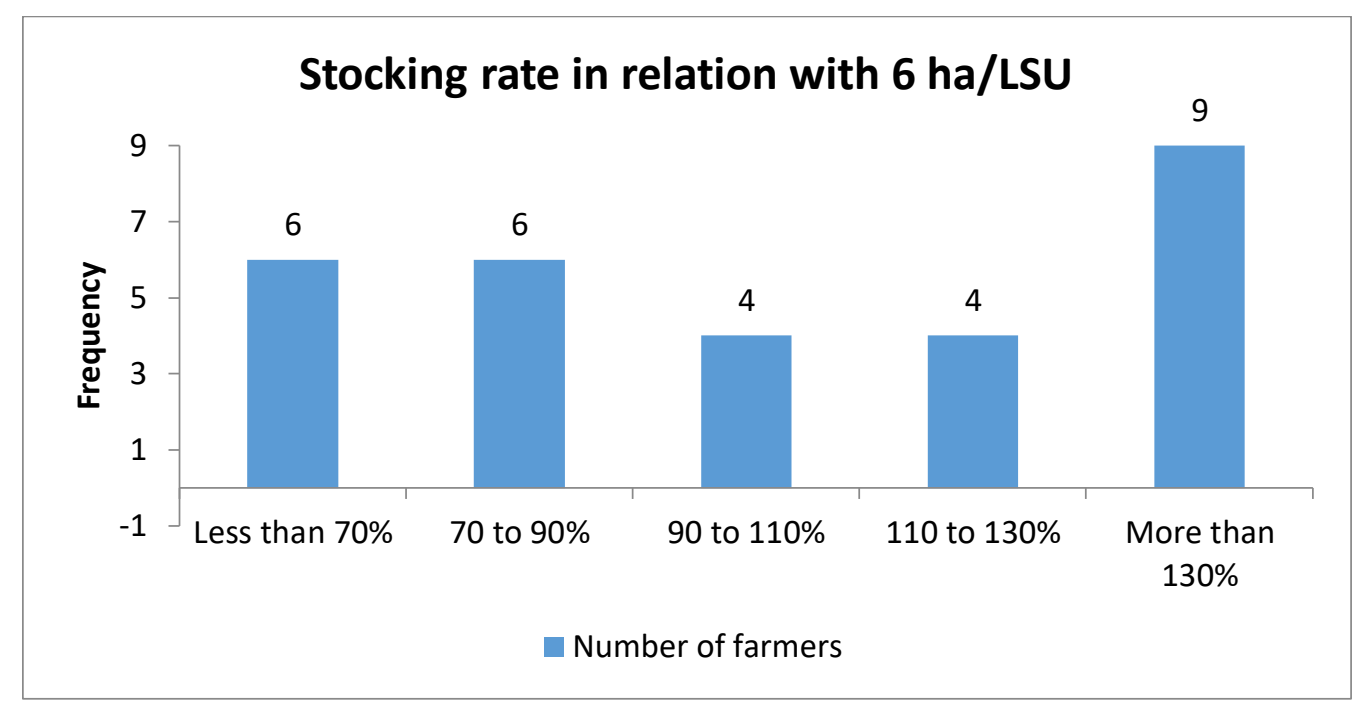

FIGURE 2: Histogram of stocking rate ranges in relation with veld in a good condition (6 ha/LSU) reported by the farmers

Although the average stocking rate for land-reform livestock farmers in Bloemfontein was observed to concede with the recommended grazing capacity for veld in good condition, six farmers (21\%) reported exceptionally low stocking rates, and nine farmers (31\%) reported extremely high stocking rates. Four of the nine farmers with extremely high stocking rates reported stocking rates of more than $300 \%$ in comparison with veld in good condition. These findings highlighted that $31 \%$ of the sampled Bloemfontein land-reform livestock farmers were totally overstocked, even during the drought/dry spell of 2018-2019. It is clear that these farms are not sustainable. 
TABLE 2: Mean mortality rate as a percentage of the stocking rate at 6 ha/LSU as well as calving rate ( \pm standard deviation)

\begin{tabular}{|l|l|l|}
\hline Stocking rate & Mortality \% & Calving \% \\
\hline More than $130 \%$ overstock & $32.7 \pm 50^{\mathrm{a}}$ & $32.7 \pm 28.7$ \\
\hline Rest of the farmers & $5.7 \pm 7.6^{\mathrm{b}}$ & $31.9 \pm 22.4$ \\
\hline
\end{tabular}

$\mathrm{a} \& \mathrm{~b}$ - Values in column with different superscripts differ significantly.

The mortality rate of the $31 \%$ of the sampled Bloemfontein land-reform farmers, who were overstocked, was also significantly higher $(\mathrm{P}<0.05)$ in comparison with the other farmers, as illustrated in Table 2. On average, the mortality rate for these farmers was $32.7 \%$ of the optimal grazing capacity of 6 ha/LSU, while farmers with more moderate stocking rates on average only lost $5.7 \%$ of LSU's. Key to note was the fact that no relation between stocking rate and calving rate could be found from data as reported by the farmers.

Average calving rates were, however, exceptionally low and comparable to the results of Van der Westhuizen et al. (2020) of 32\% obtained with very little or no rangeland management inputs. This trial was executed over a five-year period on the Glen experimental farm of the Free State Department of Agriculture and Rural Development in the Bloemfontein district. The authors highlighted the essential role of sustainable rangeland management in drought and the impact on mitigation, where reproduction of beef cattle was significantly higher during a dry season with sustainable rangeland management in comparison with a normal year, with no rangeland management inputs.

All respondents in this study were requested to make a comparison of their available natural fodder with that of their neighbours, by mere observation, to assess if there was general uniformity on available forage.

TABLE 3: Respondents' forage scarcity in comparison to that of their neighbours, average stocking rate as well as average mortality rate during drought/dry spell of 2018-2019

\begin{tabular}{|l|c|c|c|c|}
\hline $\begin{array}{l}\text { Forage in relation with } \\
\text { neighbours }\end{array}$ & Frequency & $\begin{array}{l}\text { Percentage } \\
(\boldsymbol{\%})\end{array}$ & $\begin{array}{l}\text { Stocking rate } \\
(\boldsymbol{\%})\end{array}$ & $\begin{array}{l}\text { Mortality rate } \\
(\boldsymbol{\%})\end{array}$ \\
\hline Better & 12 & 41.4 & 88 & 6.5 \\
\hline Same & 6 & 20.7 & 147 & 14.0 \\
\hline Worse & 11 & 37.9 & 378 & 22.4 \\
\hline Total & 29 & 100.0 & & \\
\hline
\end{tabular}

In the study, $41.4 \%$ of the respondents, the biggest portion of the sampled group, observed that their available fodder was better than that of their neighbours. Moreover, $20.7 \%$ of the respondents observed that their available fodder was similar to that of their neighbours, and $37.9 \%$ of the total respondents, the second-biggest portion of the sampled group, observed that their available fodder was worse than that of their neighbours. 
Although not significant, a clear trend was found between available fodder and stocking rate, as well as available fodder and mortality rate, as reported by respondents. The average stocking rate of the farms with less fodder available than their neighbours (378\%) contributed to both forage shortages and higher mortality rates $(22.4 \%)$. These findings clearly point out that there was no uniformity in terms of available fodder between the respondents. However, even though it is essential to note that livestock management systems might differ from one farmer to the next, the $37.9 \%$ is not simply a fraction of the respondents. As a result, a close monitoring and more detailed assessment of production systems and stocking rates for land-reform livestock farmers in Bloemfontein are recommended. Nonetheless, the average calving rate on farms with less fodder available during the drought was significantly higher $(\mathrm{P}<0.05)$ at $45 \%$ in comparison with the rest of the farms with an average calving rate of $25 \%$. In practice, these findings might suggest that farmers with higher livestock production skills, unfortunately, possess lower fodder management skills, which might be a serious threat to sustainable extensive livestock production.

Drought/dry spell drastically reduces the availability and nutritional value of the available fodder for livestock grazing. Nonetheless, the literature consistently agrees with the fact that the lack and poor quality of natural fodder in extensive livestock farming systems increase the susceptibility of livestock to diseases, leading to subsequent livestock deaths. Total livestock mortality of 176.8 LSUs for sampled farmers (Table 1) was recorded during the period of this study. This equates to R 1760 920.87 based on the average class B2/B3 beef carcass price for November 2018 of R42.39/kg, which is an enormous financial loss incurred by farmers when converted to monetary value. On average, each farmer from the total sampled group lost 6.1 LSUs, as observed in Table 1. This means that, on average, each farmer incurred R 60766.65 financial losses. The losses varied from old cows/ewes/does to offspring. However, the older breeding stock accounted for more than $80 \%$ of the entire losses. The loss of breeding stock is a major setback in livestock farming since it can take years to rebuild the breeding stock.

\section{CONCLUSION AND RECOMMENDATIONS}

\subsection{Conclusion}

Bloemfontein land-reform farmers' average stocking rate indicated positivity in comparison to the departmental stocking rate norm of $6 \mathrm{ha} / \mathrm{LSU}$. At the time, rainfall data indicated successive years of below average rainfall and a significant proportion of the sampled farmers observed their natural fodder availability as worse than that of their neighbouring farms. It is thus concluded that the positive relationship is spurious. The stocking rate of $21 \%$ of the respondents was exceptionally low, resulting in a loss of income for these farmers, while $31 \%$ of the respondents' stocking rates were extremely high, which will contribute to rangeland degradation, unsustainability, and poverty. Mortality rates of livestock were also high for the farmers who were severely overstocked. They lost on average $32.7 \%$ of livestock that can be kept on the farms in optimal conditions during the 2018/2019 drought. The fact that rangeland condition was not evaluated could further indicate that the stocking rate of the vast majority of farmers is too high for sustainability. According to Van der Westhuizen (2003), 
the grazing capacity for rangelands in moderate conditions (50\%) is roughly 8 ha/LSU for cattle and $9.5 \mathrm{ha} / \mathrm{LSU}$ for sheep for the study area.

In terms of available fodder, $38 \%$ of the respondents reported fodder shortages, with available fodder less than on neighbouring farms. On average, the farmers with fodder shortages were severely overstocked during the drought, and livestock mortalities for this group of farmers was $22 \%$. As a result, the continued viability of these farming operations is in jeopardy. Calving rates, as reported by farmers, were also exceptionally low, with an average of $32 \%$ and a standard deviation of $24 \%$. According to Van der Westhuizen et al. (2020), low calving rates can be classified as the main financial driver in terms of profitability for extensive livestock farming systems.

Due to climate change and global warming, the effect of the correct stocking rates will play a major role in the sustainability of Bloemfontein's extensive land-reform livestock farmers. Imprudent grazing management practices, especially pertaining to the veld, already under stress prior to the onset of drought, is one of the most important contributing factors to the devastation caused by the drought (Coleman, 2017). Dry years, particularly when they occur in succession, can reduce perennial plant cover and reduce the number of animals the veld is able to support (Van der Westhuizen et al., 2018). It is recommended that livestock numbers be reduced during extended drought periods. Stocking rates, according to grazing capacity, as well as the timely adjustment of stocking rates during droughts, are essential to promote sustainable utilisation of natural veld and subsequently to ensure sustainable productivity on extensive livestock farming systems.

Bembridge (1986) and Mokhesengoane (2020) emphasized the importance of educational programmes on the formulation of veld management programmes and veld assessment for farmers. Education of farmers on rangeland management, livestock reproduction performance and economics has a major role to play in their decision-making process when managing their rangelands. Farmers, extension personnel and rangeland scientists have a major role to play in this regard in order to reduce or prevent future rangeland degradations.

\subsection{Recommendations}

It is recommended that the extension personnel of the Bloemfontein ward office develop systems to closely assess and monitor livestock production systems and veld management programmes utilized by land reform livestock farmers to narrow $38 \%$ of the respondents, who observed their available fodder as worse than that of their neighbours.

It is also recommended that these personnel must arrange intensive training on rangeland degradations and stocking rate alignment with natural forage scarcity periods for their land-reform livestock farmers. 


\section{ACKNOWLEDGEMENTS}

The authors are grateful for the contribution of Mr. Johan van den Berg, a senior Climatologist and Manager Specialized Crop Insurance at Santam Crop Insurance, for his guidance and enormous contribution in this study about long-term rainfall pattern analyses.

\section{REFERENCES}

ACOCKS, J.P.H., 1988. Veld types of South Africa. Memoirs of the Botanical Survey of South Africa. Pretoria: Government Printer.

BEMBRIDGE, T.J., 1986. 'n Uitdaging vir landbouvoorligting. Journal of the Grassland, vol. 3:159163.

BAUDION, M., VOGEL, C., NORTJE, K. \& NAIK, M., 2017. Living with drought in South Africa: Lessons learnt from the recent El Niño drought period. International Journal of Disaster Risk Reduction, 23:128-137.

COLEMAN, A., 2017. Always manage grazing with drought in mind. Farmers Weekly, 7 June 2017.

CROS, M.J., DURU, M., GARCIA, F. \& MARTIN-CLOUAIRE L,R., 2004. Simulating management strategies: The rotational grazing example. Agricultural Systems, 80:23-42.

DANKWERTS, J.E. \& TAINTON, N.M., 1996. Available biomass and carrying capacity. Range management: Optimizing forage production and quality. Bulletin of the Grassland Society of Southern Africa, 7(1):36-50.

DEPARTMENT OF AGRICULTURE, 2003. Free State Province. Map compiled by Farming Information Section.

DU TOIT, P.F., AUCAMP, A.J. \& BRUWER, J.J., 1991. The national grazing strategy of the Republic of South Africa: Objectives, achievements and future challenges. Journal of the Grassland Society of Southern Africa, vol. 8:126-130.

DU PREEZ, C.C. \& SNYMAN, H.A., 1993. Organic matter content of a soil in a semi-arid climate with three long-standing veld conditions. African Journal of Range and Forage Science, vol. 10:108-110.

FORBES, T.D.A., 1988. Researching the plant-animal interface: The investigation of ingestive behaviour in grazing animals. Journal of Animal Science (66):2369-2379.

FOSTER, L.A., 2015. The profitability and production of a beef herd on transitional Cymbopogon Themeda veld receiving three different levels of lick supplementation. D. Tech Agric. thesis. Central University of Technology Free State, pp. 15-16.

FYNN, R.W.S. \& O'CONNOR, T.G., 2000. Effect of stocking rate and rainfall on rangeland dynamics and cattle performance in a semi-arid savanna, South Africa. Journal of Applied Ecology, 37:491-507.

MEISSNER, H.H., HOFMEYR, H.S., VAN RENSBURG, W.J.J. \& PIENAAR, J.P., 1983. Classification of livestock for realistic prediction of substitution values in terms of a biologically defined Large Stock Unit. Technical Communication no. 175. Pretoria: The Government Printer. 
MOKHESENGOANE, T.E., 2020. Land reform farmers stocking rate pattern during extended dormancy season: Bloemfontein grassland biome case study. MSA mini-dissertation, University of the Free State, Bloemfontein, South Africa. 53 pp.

MWORIA, J.K., MNENE, W.N., MUSEMBI, D.K. \& REID, R.S., 1997. Resilience of soils and vegetation subjected to different grazing intensities in a semi-arid rangeland of Kenya. African Journal of Range and Forage Science, vol. 14:26-31.

O'CONNOR, T.G., KUYLER, P., KIRKMAN, K.P. \& CORCORAN, B., 2010. Which grazing management practices are most appropriate for maintaining biodiversity in South African grassland? African Journal of Range \& Forage Science, 27(2):67-76.

SANBI, 2014. Grazing and burning guidelines: Managing grassland biodiversity and livestock production. Compiled by Lechmere-Oetel, R.G. South African National Biodiversity Institute,Pretoria, $42 \mathrm{pp}$.

SWEMMER, A.M., BOND, W.J., DONALDSON, J., HEMPSON, G.P., MALHERBE, J. \& SMIT, I.P.J., 2018. The ecology of drought - A workshop report. South African Journal of Science, 114(9/10):1-3.

VAN DEN BERG, J., 2019. Long term rainfall pattern analysis report for the Bloemfontein area. Santam Crop Insurance.

VAN DER WESTHUIZEN, H.C., 2003. Die gebruik van degradasiegradiënte vir weiveldevaluering in 'n semi-ariede gebied. Ph.D. thesis, University of the Orange Free State, Bloemfontein, South Africa. 444 pp.

VAN DER WESTHUIZEN, H.C., 2006. Weiveldevaluering vir optimale hulpbron benutting. Nguni $J ., 2006: 13-33$.

VAN DER WESTHUIZEN, H.C., 2020. Volhoubare veldbestuur and soet veld gebiede. Veeplaas December 2020.

VAN DER WESTHUIZEN, H.C., MOHLAPO, T.D., DE KLERK, J.D., MAJOLA, S.E., SNYMAN, H.A. \& NESER, F.W.C., 2020. Reproduction performance of beef cattle before and after implementing a sustainable grazing system in a semi-arid grassland of southern Africa. South African Journal of Agricultural Extension, 48(1):112-121.

VAN DER WESTHUIZEN, H.C., SNYMAN, H.A. \& FOUCHÉ, H.J., 2018. Sustainable veld management guidelines for the Free State. Glen Research Periodical FSDARD, 1:27-59.

VAN DER WESTHUIZEN, H.C., SNYMAN, H.A., VAN RENSBURG, W.L.J. \& POTGIETER, J.H.J., 2001.The quantification of grazing capacity from grazing and production values for forage species in semi-arid grasslands of southern Africa. African Journal of Range \& Forage Science, 18(1):43-52.

ZUMA-NETSHIUKHWI, G.N.C. \& STIGTER, C.J., 2016. An extension approach to close the gap between suppliers and users of agro meteorological services in the south-western Free State of South Africa. South African Journal of Agricultural Extension, 44(2):84-98. 